\begin{tabular}{|c|c|c|c|c|}
\hline \multirow{3}{*}{$\begin{array}{l}\text { 2. ECN Category } \\
\text { (mark one) } \\
\text { Suppl emental } \\
\text { Direct Revision } \\
\text { Change ECN }\end{array}$} & \multicolumn{2}{|c|}{$\begin{array}{l}\text { 3. Originator's Name, Organization, MSIN, } \\
\text { and Telephone No. } \\
\text { JR Green/84100-G1-11/376-0610 }\end{array}$} & $\begin{array}{l}\text { 3a. UsQ Required? } \\
{[1 \text { Yes }[X] \text { No }}\end{array}$ & $\begin{array}{l}\text { 4. Date } \\
06 / 18 / 96\end{array}$ \\
\hline & \multicolumn{2}{|c|}{$\begin{array}{l}\text { 5. Project title/No./Work order No. } \\
\text { MCO Packaging }\end{array}$} & $\begin{array}{c}\text { 6. Bldg./Sys./Fac. No. } \\
\text { NA }\end{array}$ & $\begin{array}{c}\text { 7. Approval Designator } \\
\text { S }\end{array}$ \\
\hline & \multicolumn{2}{|c|}{$\begin{array}{l}\text { 8. Document Numbers Changed by this ECN } \\
\text { (includes sheet no. and rev.) } \\
\text { WHC-SD-TP-RPT-022, Rev. } 0\end{array}$} & $\begin{array}{l}\text { 9. Related ECN No(s). } \\
\text { NA }\end{array}$ & $\begin{array}{l}\text { 10. Related PO No. } \\
\text { NA }\end{array}$ \\
\hline \multirow{2}{*}{$\begin{array}{l}\text { 11a. Modification Work } \\
\text { [] Yes (fill out Blk. } \\
11 \mathrm{~b}) \\
{[X] \text { No (NA Blks. 11b, }} \\
11 c, 11 \mathrm{~d})\end{array}$} & \multirow[t]{2}{*}{$\begin{array}{l}\text { 11b. Work Package } \\
\text { No. } \\
\text { NA }\end{array}$} & $\begin{array}{l}\text { 11c. Modification Work Complete } \\
\text { NA }\end{array}$ & \multicolumn{2}{|c|}{$\begin{array}{l}\text { 11d. Restored to Original Condi- } \\
\text { tion (Temp. or Standby ECN only) } \\
\text { NA }\end{array}$} \\
\hline & & \multicolumn{2}{|c|}{ Cog. Engineer Signature \& Date } & neer signature \& Date \\
\hline \multicolumn{5}{|c|}{$\begin{array}{l}\text { 12. Description of Change } \\
\text { The Multiple Canister Overpack shipping campaign risk assessment was changed to include } \\
\text { shipping from the } K \text { Basins to a Cold Vacuum Drying Facility. The new shipment leg may } \\
\text { use a different cask configuration than the configuration used for shipments to the } \\
200 \text { East Area. The report was also changed to reflect new Hanford truck accident } \\
\text { statistics and to take advantage of reduction factors associated with administrative } \\
\text { controls. }\end{array}$} \\
\hline
\end{tabular}

12. Description of Change

The Multiple Canister Overpack shipping campaign risk assessment was changed to include shipping from the $K$ Basins to a Cold Vacuum Drying Facility. The new shipment leg may use a different cask configuration than the configuration used for shipments to the 200 East Area. The report was also changed to reflect new Hanford truck accident statistics and to take advantage of reduction factors associated with administrative controls.

13a. Justification (mark one)

[X] Environmental

13b. Justification Detai is

Change in the scope of the risk assessment. New statistics based on current data.

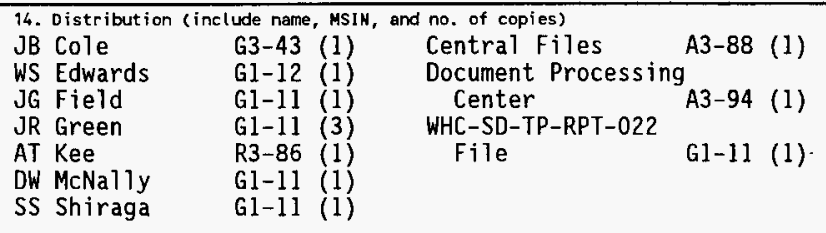

$A-7900-013-2(11 / 94)$ GEF095 


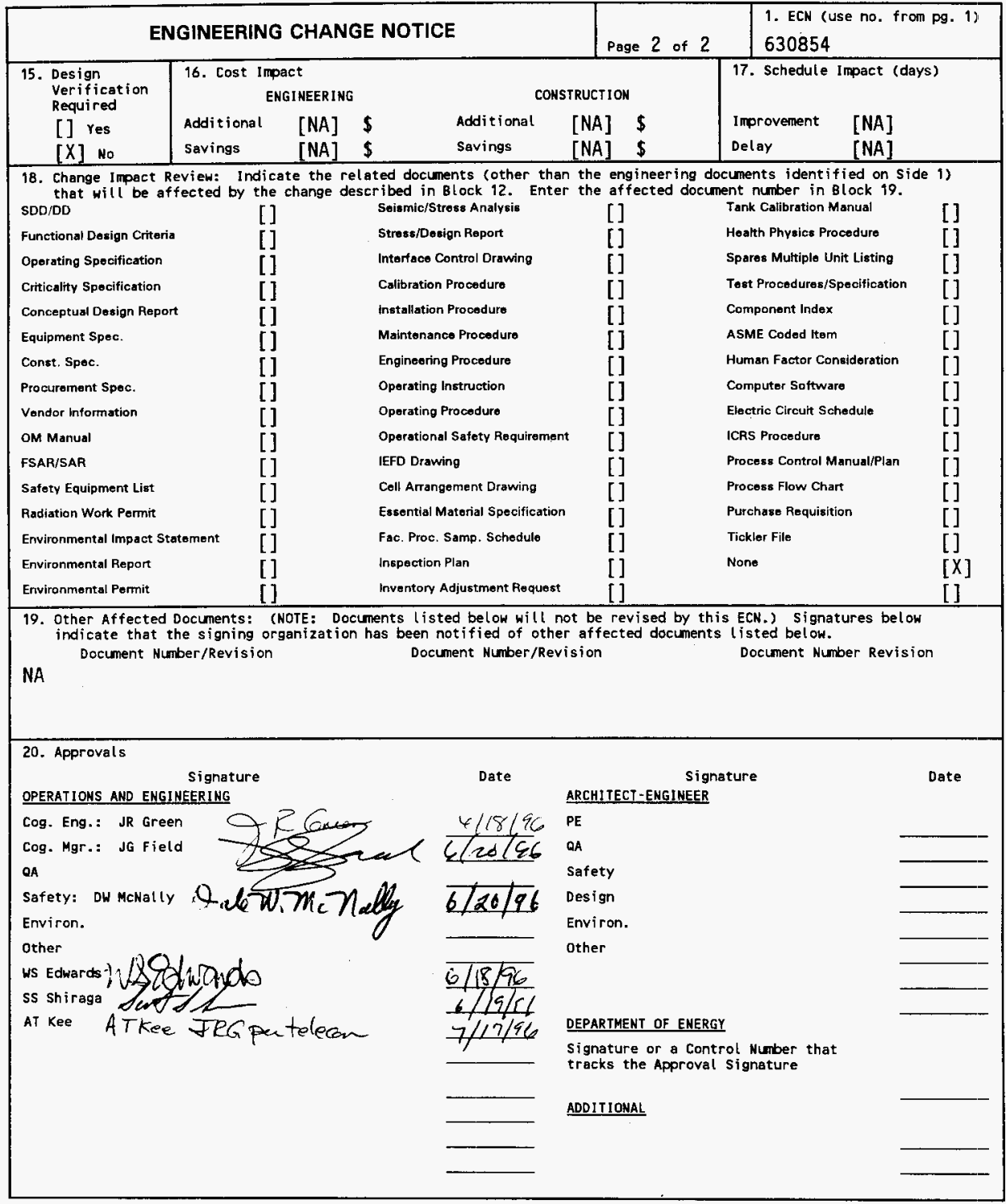




\title{
Radiological Risk Evaluation for Risk-Based Design Criteria of the Multiple Canister Overpack Packaging
}

\section{J. R. Green}

Westinghouse Hanford Company, Richland, WA 99352

U.S. Department of Energy Contract DE-ACO6-87RL10930

\author{
EDT/ECN: $630854 \quad$ UC: 513 \\ Org Code: $84100 \quad$ Charge Code: LF037 \\ B\&R Code: EW3135040 Total Pages: 18
}

Key Words: risk assessment methodology, MCO cask

Abstract: The Multiple Canister Overpack (MCO) cask will be used in the transportation of irradiated nuclear fuel from the $K$ Basins to a

Canister Storage Building. This report presents the radiological risk evaluation, which is used in the development of the design criteria for the MCO cask. The radiological risk evaluation ensures compliance with the onsite transportation safety program.

TRADEMARK DISCLAIMER. Reference herein to any specific conmercial product, process, or service by trade name, trademark, manufacturer, or otherwise, does not necessarily constitute or imply its endorsement, recommendation, or favoring by the United States Governnent or any agency thereof or its contractors or subcontractors.

Printed in the United States of America. To obtain copies of this document, contact: HHC/BCS Document Control Services, P.O. Box 1970, Mailstop H6-08, Richland 4 A 29352 , Phone (509) $372-2420$; Fax (509) 376-4989.
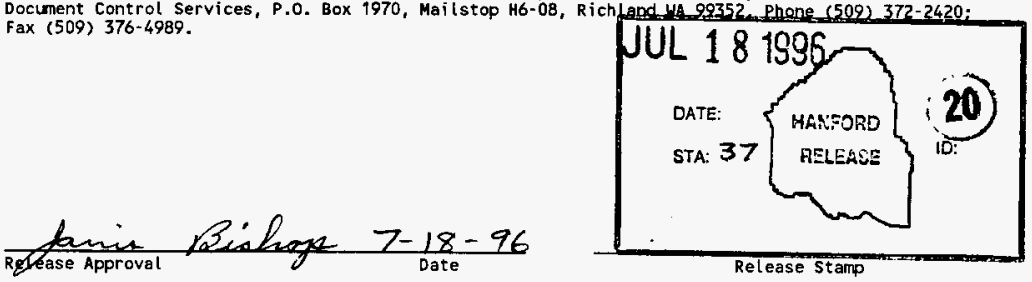


\begin{tabular}{|c|c|c|c|c|}
\hline \multicolumn{2}{|r|}{ RECORD OF REVISION } & \multicolumn{2}{|c|}{$\begin{array}{l}\text { (1) Document Number } \\
\text { WHC-SD-TP-RPT-022 }\end{array}$} & Page 1 \\
\hline \multicolumn{5}{|c|}{$\begin{array}{l}\text { (2) Title } \\
\text { Radiological Risk Evaluation for Risk-Based Design Criteria of the Multiple Canister } \\
\text { Overpack Packaging }\end{array}$} \\
\hline \\
\hline \multirow{2}{*}{ (3) Revision } & \multirow{2}{*}{$\begin{array}{l}\text { CHAMGE CONTROL RECORD } \\
\text { (4) Description of change - Replace, Add, and Delete Pages }\end{array}$} & \multicolumn{3}{|c|}{ Authorized for Release } \\
\hline & & (5) Cog. Engr. & (6) 0 & gr. Date \\
\hline 0 & (7) EDT 611499 , dated $08 / 21 / 95$. & & & \\
\hline 1 RS & $\begin{array}{l}\text { The Multiple Canister Overpack shipping } \\
\text { campaign risk assessment was changed to } \\
\text { include shipping from the } K \text { Basins to a } \\
\text { Cold Vacuum Drying Facility. The new } \\
\text { shipment leg may use a different cask } \\
\text { configuration than the one used for } \\
\text { shipments to the } 200 \text { East Area. The report } \\
\text { was also changed to reflect new Hanford } \\
\text { truck accident statistics and to take } \\
\text { advantage of reduction factors associated } \\
\text { with administrative controls. Replace all } \\
\text { pages. ECN } 630854 \text {. }\end{array}$ & $\begin{array}{l}\text { JR Green } \\
\text { P/R Grew } \\
4 / 18196\end{array}$ & & 6 \\
\hline & & & & \\
\hline & & & & \\
\hline & & & & \\
\hline & & & & \\
\hline & & & & \\
\hline & & & & \\
\hline & & & & \\
\hline & & & & \\
\hline & & & & \\
\hline & & & & \\
\hline & & & & \\
\hline & & & & \\
\hline & & & & \\
\hline & & & & \\
\hline & & & & \\
\hline & & & & \\
\hline & & & & \\
\hline & & & & \\
\hline & & & & \\
\hline & & & & \\
\hline & & & & \\
\hline & & & & \\
\hline & & & & \\
\hline & & & & \\
\hline & & & & \\
\hline
\end{tabular}


WHC-SD-TP-RPT-022 Rev. 1

\section{CONTENTS}

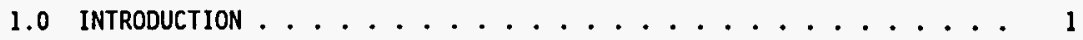

2.0 RISK ACCEPTANCE CRITERIA . . . . . . . . . . . . 2

3.0 DOSE CONSEqUENCE ANALYSIS RESULTS ............. 3

4.0 ACCIDENT FREQUENCY ASSESSMENT $\ldots \ldots \ldots \ldots$

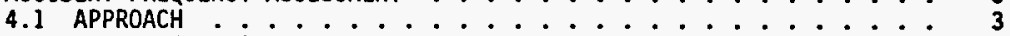

4.2 ACCIDENT RELEASE FREQUENCY ANALYSIS $\ldots \ldots \ldots$

5.0 SUMMARY OF RISK-BASED DESIGN CRITERIA ........... 10

6.0 REFERENCES ................................... 14

\section{LIST OF TABLES}

1 Risk Acceptance Criteria Limits . . . . . . . . . . . 2

2 Cold Vacuum Drying Normal Transport ............ 5

3 Central Storage Building Normal Transport ............ 7

4 Summary of Options for Design Criteria and Administrative Controls . . 11 
WHC-SD-TP-RPT-022 Rev, 1

\section{LIST OF TERMS}

$\begin{array}{ll}\mathrm{cm} & \text { centimeter } \\ \mathrm{CSB} & \text { Canister Storage Building } \\ \mathrm{CVD} & \text { Cold Vacuum Drying (Facility) } \\ \mathrm{in} . & \text { inch } \\ \mathrm{kg} & \text { kilogram } \\ \mathrm{km} & \mathrm{kilometer} \\ \mathrm{km} / \mathrm{h} & \text { kilometers per hour } \\ \mathrm{lb} & \text { pound } \\ \mathrm{MCO} & \text { Multiple Canister Overpack } \\ \mathrm{mi} & \text { mile } \\ \mathrm{mph} & \text { miles per hour } \\ \text { TEDE } & \text { total effective dose equivalent }\end{array}$


WHC-SD-TP-RPT-022 Rev, 1

\section{RADIOLOGICAL. RISK EVALUATION FOR RISK-BASED \\ DESIGN CRITERIA OF THE MULTIPLE \\ CANISTER OVERPACK PACKAGING}

\subsection{INTRODUCTION}

The Multiple Canister Overpack (MCO) cask will be used in the transportation of approximately 2,100 metric tons of unprocessed, irradiated nuclear fuel presently stored in the K Basins. The MCO cask will act as the primary containment vessel during transportation. There will be two legs to the shipments. The first leg will be transport of the casks by roadway from the $K$ Basin to a Cold Vacuum Drying (CVD) Facility located in the 100 Area within $0.8 \mathrm{~km}(0.5 \mathrm{mi})$ of the $\mathrm{K}$ Basins, referred to as CVD transport. The second leg will cover $12.8 \mathrm{~km}(8 \mathrm{mi})$ and will transport the casks by highway from the CVD to a Canister Storage Building (CSB) in the 200 East Area, referred to as CSB transport.

The MCO and MCO cask will be used for both shipments; however, it is possible that the MCO and MCO cask will have different configurations and failure thresholds for the two different legs. Also, during the CVD transport, the fuel will be shipped wet, and the MCO may be unsealed. During the CSB transport, the fuel will be dry and the MCO sealed. Transport to the CVD from the $K$ Basins will cover a short distance on roadways within the 100 Area where traffic volume is lower than on the main highways of the Hanford Site. Transport from the CVD to the CSB will take place on Hanford Site highways. Radiological risks for both the CVD transport and the CSB transport will be evaluated to aid in determining design criteria for the two configurations of the MCO cask.

The $K$ Basin campaign will extend for a period of two years. For both transport legs, only the highway mode will be considered. The casks will contain the $\mathrm{N}$ Reactor and Single Pass Reactor fuel that is currently stored in the $K$ Basins. In addition, the sludge in the basins may contain small fuel particles and fission products and may also be shipped in MCO casks. The assumptions for the radiological risk evaluations common for both transports are:

Highway mode

270 fuel elements (or equivalent sludge) per cask

One cask per shipment

400 total shipments

200 shipments per year

Weight of cask plus cask contents: 27 metric tons (30 tons)

Gross vehicle weight: 41 metric tons (45 tons).

The cask and cask contents are assumed to weigh $27,000 \mathrm{~kg}(60,000 \mathrm{lb})$, the trailer and truck $14,000 \mathrm{~kg}(30,000 \mathrm{1b})$. These parameters are used in determining conditional probabilities for the highway mode. They produce conservative values for shipments of greater weight. 
WHC-SD-TP-RPT-022 Rev. 1

The assumptions specific to the CVD and CSB transports are the following:

CVD Transport:

$0.8 \mathrm{~km}(0.5 \mathrm{mi})$ per shipment

Water-covered fuel

MCO may be unsealed

CSB Transport:

$12.8 \mathrm{~km}(8 \mathrm{mi})$ per shipment

Dry fuel

Sealed MCO

The MCO cask will be designed to withstand normal transportation conditions and onsite accident environments. The cask will meet onsite transportation safety requirements per WHC-CM-2-14, Hazardous Material Packaging and Shipping, and as outlined in the Report on Equivalent Safety for Transportation and Packaging of Radioactive Material (Mercado 1994). An iterative process is used to ascertain design criteria that provide the requisite safety. The process combines dose consequences, failure threshold values, annual accident frequencies, and, in some cases, the addition of appropriate administrative controls. The resulting design criteria are based on accident conditions, as specified for impact, crush, puncture, and fire. Risk acceptance criteria are outlined in Section 2.0. The results of the dose consequence analyses are provided in Section 3.0 . The analys is of accident release frequencies for associated failure thresholds is given in Section 4.0. The accident frequencies and dose values provide the necessary input for evaluating the acceptability of the risks related to specific design criteria. Section 5.0 lists the risk-based design criteria and associated administrative controls developed in the previous sections.

\subsection{RISK ACCEPTANCE CRITERIA}

Graded dose limitations for probable, credible, and incredible accident frequencies ensure safety in onsite radioactive material packaging and transportation (Mercado 1994). The dose limitations to the onsite and offsite receptors for probable, credible, and incredible accident frequencies are presented in Table 1 . The limits are total effective dose equivalents (TEDE). The TEDE is the sum of the external dose and the internal committed effective dose equivalent integrated over 50 years.

Table 1. Risk Acceptance Criteria Limits.

\begin{tabular}{|l|l|l|l|}
\hline \multicolumn{1}{|c|}{ Description } & \multicolumn{1}{|c|}{ Annual frequency } & Offsite dose limit ${ }^{*}$ (rem) & Onsite dose timit ${ }^{*}$ (rem) \\
\hline Incredible & $<10^{-7}$ & None & None \\
\hline Incredible & $10^{-7}$ to $<10^{-6}$ & 25 & None \\
\hline Credible & $10^{-6}$ to $10^{-3}$ & $0.5 / 1.5 / 5$ & $5 / 15 / 50$ \\
\hline Probable & $10^{-3}$ to 1 & $0.01 / 0.03 / 0.1$ & $0.2 / 0.6 / 2$ \\
\hline
\end{tabular}

*Estimated dose equivalent/lens of eye/all other organs 


\subsection{DOSE CONSEQUENCE ANALYSIS RESULTS}

The preliminary dose consequence study for the Mco Cask, presented in Rev. 0 of this document, was a scoping estimate originally performed in August 1995. The analysis was based on a preliminary source term available at that time, which underestimated the inventory per MCO. The analysis resulted in doses that required accident release frequencies to be less than $10^{-6}$. The current inventory presented in the packaging design criteria has more than doubled the activities of the isotopes that drive the dose consequence results. In particular the activity for the two highest inhalation dose contributors, ${ }^{241} \mathrm{Am}$ and ${ }^{239} \mathrm{Pu}$, are five and two times Targer than the original source term. This will more than double the doses reported in the original analysis and wi11 result in criteria limits in a higher category. Therefore, accident releases for this analysis are assumed to require release frequencies in the most restrictive range, that is, less than $10^{-7}$.

\subsection{ACCIDENT FREQUENCY ASSESSMENT}

\subsection{APPROACH}

The accident frequency assessment is based on the assumption that a single failure mode is appropriate for each of the different forces described as impact, crush, puncture, and fire. Package failure frequencies from different scenarios with similar consequences and the same type of force are summed to determine a composite failure mode for analysis.

The frequency (F) of a truck accident is the product of the annual number of trips, the number of miles per trip, and the accident rate per mile.

$F=$ number of trips/year $x$ miles/trip $x$ accidents/mile

Hanford Site truck accidents have been compiled in a report using Hanford Site data (Green et al. 1996). The resulting yearly accident rate calculated for trucks is $2.0 \times 10^{-7}$ accidents per mile. A risk management study performed by H\&R Technical Associates (H\&R 1995) has identified reduction factors that can be used to reduce the Hanford Site accident rate when administrative controls are enforced during shipment of radioactive material. These reduction factors are summarized below.

Reduction Factor

2

18.25
Administrative Control

Areas with markedly less traffic (100 Area)

Vehicle is accompanied by escort vehicles

Shipment during nonpeak hours with escorts, road

closure, and prior notification of emergency responders

A decrease in the volume of traffic will result in much lower accident rates. Escorting vehicles will also reduce the accident rate of the transporting truck. In the 100 Area it is possible that the roadways between 


$$
\text { WHC-SD-TP-RPT-022 Rev. } 1
$$

the $K$ Basins and the CVD facility will become a limited area and that onty the transporting vehicle will be allowed on the roadway. In this situation, a reduction factor of up to 18.25 can be used.

The values for $F$ for the two shipment legs are found using the shipment data and the accident rate determined for the Hanford Site. Reduction factors have also been used to give some variation in the design features. Less restrictive design features require more administrative control. The spreadsheets represented in Tables 2 and 3 show the values of $F$ with the reduction factors added as needed.

The frequency of accidents is multiplied by the sum of the conditional release probabilities of the specific failure modes to arrive at an annual accident release frequency. Conditional release probabilities for fire, crush, impact, and puncture are determined from a Sandia National Laboratory study for accidents involving large packages (Dennis et a1. 1978) and from the Hanford Site risk management study performed by H\&R Technical Associates (H\&R 1995). One additional administrative control can be used to lower conditional release probabilities. If a speed limit is enforced below the impact failure threshold velocity and the shipments are escorted to reduce impact collisions from other vehicles, the conditional probability of occurrence of an impact failure is reduced essentially to zero. This administrative control has been used in one of the options for the CVD leg. The conditional release probabilities are shown in Tables 2 and 3 . The resulting accident release frequencies from the product of $F$ and the conditional release probability are then used in determining compliance with onsite transportation requirements.

\subsection{ACCIDENT RELEASE FREQUENCY ANALYSIS}

Accident sequence analysis is developed for each failure type (impact, puncture, crush, and fire) and shown in Tables 2 and 3 , which depict the design criteria options for both the CVD and CSB transports. Failure thresholds depict the condition for the accident type in question at which the cask will no longer provide confinement, shielding, or criticality control. A cask impact failure, for instance, could occur at that force required to. cause loss of the cask lid. For impact, the failure threshold is expressed in terms of the velocity change of the cask required to mechanically fail the package. Puncture and crush, likewise, are mechanical failures. Fire is expressed in terms of the amount of time required to cause a breach in the package. On the Hanford Site, loss of the cask seals due to fire does not usualiy depict a failure because, depending on the form of the radioactive material, loss of the seals frequently will not result in loss of confinement of the materials being shipped.

Information on the probabilities of occurrence and the conditional probabilities of failure (based on duration in the case of fire) was taken from Dennis et al. (1978) and H\&R (1995). Mechanical failure conditional probabilities are not further subdivided into those affected by fire, but are represented in the mechanical failure values. 
Table 2. Cold Vacuum Drying Normal Transport. (2 sheets total)

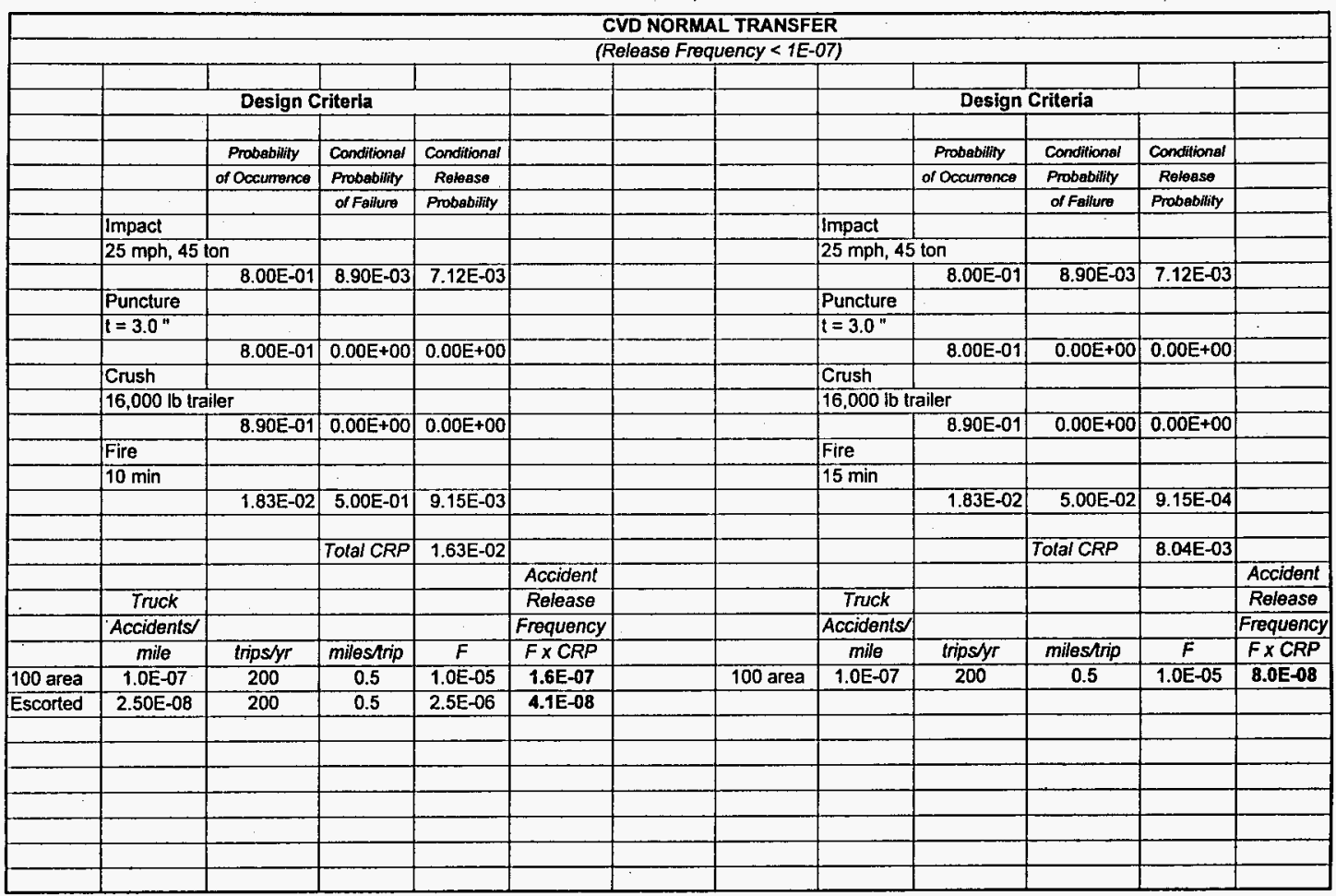


Table 2. Cold Vacuum Drying Normal Transport. (2 sheets total)

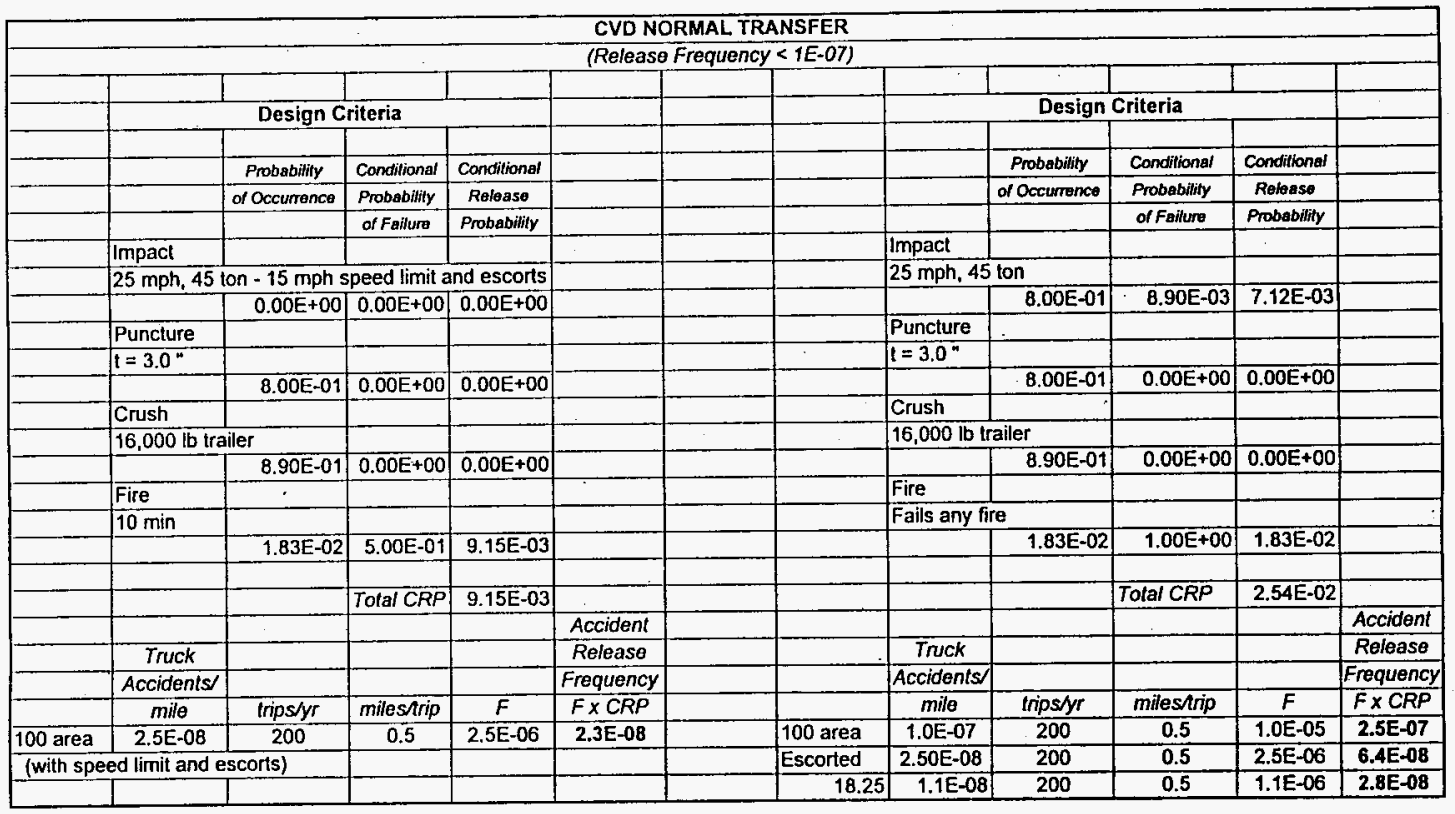


Table 3. Central Storage Building Normal Transport. (3 sheets total)

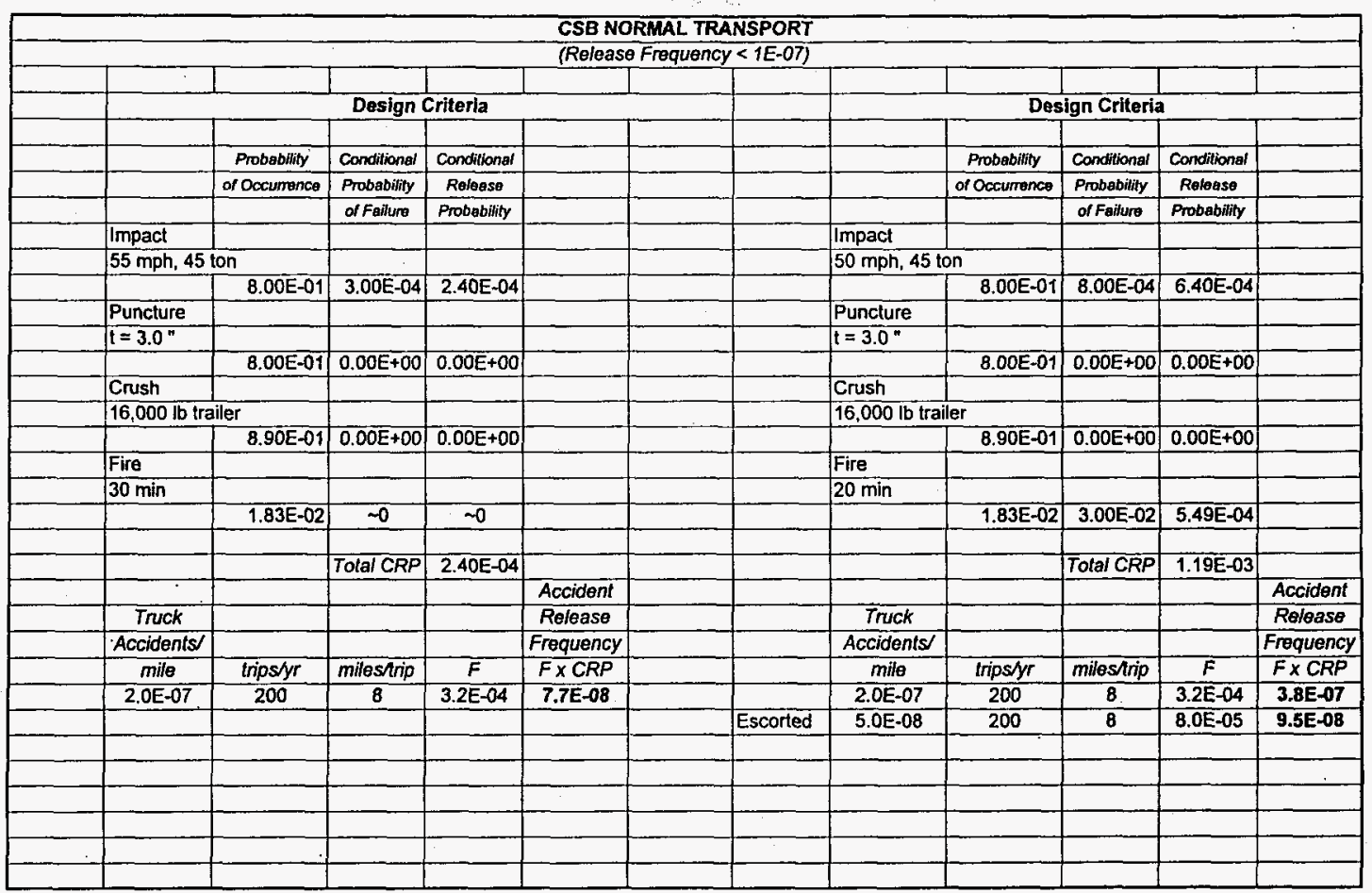


Table 3. Central Storage Building Normal Transport. (3 sheets total)

\begin{tabular}{|c|c|c|c|c|c|c|c|c|c|c|c|c|}
\hline \multicolumn{13}{|c|}{ CSB NORMAL TRANSPORT } \\
\hline \multicolumn{13}{|c|}{ (Release Frequency < 1E-07) } \\
\hline & & & & & & & & & & & & \\
\hline & \multicolumn{6}{|c|}{ Design Criteria } & & \multicolumn{5}{|c|}{ Design Criteria } \\
\hline & & & & & & & & & & & & \\
\hline & & Probability & Conditional & Conditionat & & & & & Probability & Condilional & Conditional & \\
\hline & & of Occurrence & Probability & Roloase & & & & & of Occurrence & Probability & Release & \\
\hline & & & of Foilure & Probabilliy & & & & & & of Failure & Probsobility & \\
\hline & \multicolumn{2}{|c|}{$45 \mathrm{mph}, 45$ ton } & & & & & & \multicolumn{2}{|c|}{$50 \mathrm{mph}, 45$ ton } & & & \\
\hline & & $8.00 \mathrm{E}-01$ & $1.50 E-03$ & $1.20 \overline{\mathrm{E}}-03$ & & & & & 8.00E-01 & 8.00E-04 & $6.40 \mathrm{E}-04$ & \\
\hline & Puncture & & & & & & & Puncture & & & & \\
\hline & $t=3.0^{\prime \prime}$ & & & & & & & $t=3.0^{\prime \prime}$ & & & & \\
\hline & & 8.00E-01 & $0.00 \mathrm{E}+00$ & $0.00 E+00$ & & & & & $8.00 \mathrm{E}-01$ & $0.00 \mathrm{E}+00$ & $0.00 \mathrm{E}+00$ & \\
\hline & Crush & & & & & & & Crush & & & & \\
\hline & \multicolumn{2}{|c|}{$16,000 \mathrm{lb}$ trailer } & & & & & & \multicolumn{2}{|c|}{$16,000 \mathrm{lb}$ trailer } & & & \\
\hline & & $8.90 \mathrm{E}-01$ & $0.00 \mathrm{E}+00$ & $0.00 \mathrm{E}+00$ & & & & & $8.90 \mathrm{E}-01$ & $0.00 \mathrm{E}+00$ & $0.00 \mathrm{E}+00$ & \\
\hline & $30 \mathrm{~min}$ & & & & & & & $15 \mathrm{~min}$ & & & & \\
\hline & & $1.83 \mathrm{E}-02$ & $\sim 0$ & -0 & & & & & 1.83E-02 & $5.00 E-02$ & $9.15 \mathrm{E}-04$ & \\
\hline & & & & & & & & & & & & \\
\hline & & & Total CRP & $1.20 \mathrm{E}-03$ & & & & & & Total CRP & $1.56 \mathrm{E}-03$ & \\
\hline & & & & & Accident & & & & & & & Accident \\
\hline & Truck & & & & Releaso & & & Truck & & & & Release \\
\hline & Accidents & & & & Frequency & & & Accidents/ & & & & Frequency \\
\hline & mile & tripsyr & miles/rip & $F$ & $F \times C R P$ & & & mile & tripsyr & milesinip & $F$ & $F \times C R P$ \\
\hline & $2.0 \mathrm{E}-07$ & 200 & 8 & 3.2E-04 & $3.8 E-07$ & & & $2.0 \mathrm{E}-07$ & 200 & 8 & 3.2E-04 & $5.0 E-07$ \\
\hline Escorted & $5.0 \mathrm{E}-08$ & 200 & 8 & $8.0 \mathrm{E}-05$ & 9.6E-08 & & Escorted & $5.0 \mathrm{E}-08$ & 200 & 8 & 8.0E-05 & 1.2E-07 \\
\hline & & & & & & & Roads & 1.1E-08 & 200 & 8 & 1.8E-05 & 2.7E-08 \\
\hline & & & & & & & Closed & & & & & \\
\hline
\end{tabular}




\begin{tabular}{|c|c|c|c|c|c|c|c|c|c|c|c|c|}
\hline & & & 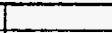 & & & & $80-32^{\prime} 6$ & $50-30 \% 8$ & 8 & 002 & $80-709$ & popoos \\
\hline & & & & & & & $\angle O-3 L E$ & प0- $\exists Z \varepsilon$ & 8 & 002 & $\angle 0-30 \mathrm{Z}$ & \\
\hline & & & & & & & dy $\times y$ & $y$ & dulsolum & $J /(\bar{s} d u)$ & epw & \\
\hline & & & & & & & Asuənbady & & & & /s\}uep!ơ & \\
\hline & & & & & & & eseajey & & & & YONII & \\
\hline & & & & & & & juap!os & & & & & \\
\hline & & & & & & & & $\varepsilon 0-\exists 9 l \mathrm{l}$ & $d 8 \supset 180_{1}$ & & & \\
\hline & & & & & & & & & & & & \\
\hline & & & & & & & & $60-3916$ & $20-300 \% 9$ & $20-918.1$ & & \\
\hline & & & & & & & & & & & ụm sl & \\
\hline & & & & & & & & & & & कम! & \\
\hline & & & & & . & & & $00+7000$ & $00+3000$ & $10-3068$ & & \\
\hline & & & & & & & & & & \multicolumn{2}{|c|}{ 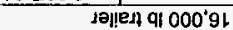 } & \\
\hline & & & & & & & & & & & $45 n+0$ & \\
\hline & & & & & & & & $00+3000$ & $00+7000$ & $10-700 ' 8$ & & \\
\hline & & & & & & & & & & & $.0 \varepsilon=1$ & \\
\hline & & & & & & & & & & & esnjound & \\
\hline & & & & & & & & $10-30072$ & $b 0-\exists 00^{\circ} \varepsilon$ & $10-\exists 008$ & & \\
\hline & & & & & & & & & & \multicolumn{2}{|c|}{ uot st '4du gs } & \\
\hline & & & & & & & & & & & pedwi & \\
\hline & & & & & & & & Altuqeqoud & annyos jo & & & \\
\hline & & & & & & & & osea/ey & Almqeqaidd & exubun2000 10 & & \\
\hline & & & & & & & & jevolupuos & pouonpuos & 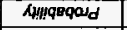 & & \\
\hline & & . & & & & & & & & & & \\
\hline & & & & & & \multicolumn{6}{|c|}{ 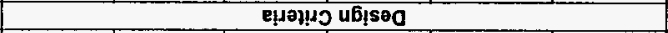 } & \\
\hline & & & & & & & & & & & & \\
\hline & & & & & & \multicolumn{7}{|c|}{ 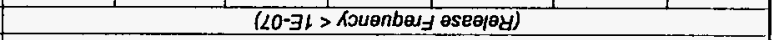 } \\
\hline & & & & & & \multicolumn{7}{|c|}{ LYOdSNVYI 7 VWYON GSO } \\
\hline
\end{tabular}

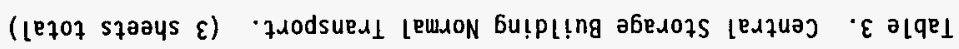


An iterative process was used, varying the conditionat probabilities of failure for the different mechanical and fire failure thresholds for the CVD and CSB transport legs. Different reduction factors were applied to increase the design criteria options. The resulting thresholds will determine the accident design criteria.

The impact failure threshold is determined for the gross vehicle weight and, as previously stated, by the velocity change of the cask that will cause mechanical failure of the package. For design purposes, the velocity change is translated into a drop onto a Hanford Site surface or a concrete surface.

Puncture probabilities are determined by the thickness of the cask walls. The MCO cask puncture criteria are determined to be $7.6 \mathrm{~cm}(3.0 \mathrm{in}$.) of steel or its equivalent. The MCO cask will need to survive the crush force from a $7,300-\mathrm{kg}(16,000-1 \mathrm{~b})$ truck trailer.

The fire failure threshold is determined by the number of minutes a cask can survive being engulfed in a $800^{\circ} \mathrm{C}\left(1,475^{\circ} \mathrm{F}\right)$ fire. The cask can lose containment due to loss of seals during a fire after $X$ minutes as long as there is no catastrophic loss of contents and no loss of MCO confinement. Additionally, there can be no significant loss of shielding during a fire incident. After the fire is extinguished, exterior cooling of the cask is permitted.

Tables 2 and 3 show the conditional release probabilities calculated for the CSB and CVD transport scenarios and sum them to give a total conditional release probability given an accident. The summed probability is then multiplied by $F$, the frequency, to arrive at an annual accident release frequency. The value of $F$ is determined by the accident rate and the application of reduction factors that require administrative controls. The criteria limits determined by the dose consequences, as presented in Section 3.0 , required an annual accident release frequency of less than $10^{-7}$.

\subsection{SUMMARY OF RISK-BASED DESIGN CRITERIA}

Table 4 summarizes the options for design criteria and administrative controls for both transport legs that fulfill onsite transportation safety requirements.

For both transport legs, the requirements for puncture and crush are the same. Puncture requires $3-i n$. equivalent steel, and the cask must survive a $7,300-\mathrm{kg}(16,000-1 \mathrm{~b})$ crush force. In addition, administrative controls that are required for onsite transport of radioactive materials also apply. For the other design elements, different options are available, depending on the nature of additional administrative controls. 
Table 4. Summary of Options for Design Criteria and Administrative Controls.

\begin{tabular}{|c|c|c|c|c|c|}
\hline & $\begin{array}{l}\text { Impact } \\
\mathrm{km} / \mathrm{h} \text { (mph) }\end{array}$ & $\begin{array}{l}\text { Puncture } \\
\text { cm (in.) }\end{array}$ & $\begin{array}{l}\text { Crush } \\
\text { kg (1b) } \\
\end{array}$ & $\begin{array}{l}\text { Firen } \\
\text { (min) }\end{array}$ & Additional adainistrative controls \\
\hline \multirow{3}{*}{$\begin{array}{l}\text { Cold Vacuun } \\
\text { Drying leg } \\
\text { (restricted to } \\
\text { 100 Area) }\end{array}$} & $40(25)$ & 7.62 (3) & $\begin{array}{r}7,300 \\
(16,000) \\
\end{array}$ & 10 & $\begin{array}{l}\text { Escorts for closed area) with } \\
\text { optional } 24 \mathrm{~km} / \mathrm{h}(15-\mathrm{mph}) \text { speed limit }\end{array}$ \\
\hline & $40(25)$ & $7.62(3)$ & $\begin{array}{r}7,300 \\
(16,000) \\
\end{array}$ & 15 & None \\
\hline & $40(25)$ & $7.62(3)$ & $\begin{array}{l}27,300 \\
(16,000)\end{array}$ & Fails & Escorts (or closed area) \\
\hline \multirow[t]{5}{*}{$\begin{array}{l}\text { Cenister storage } \\
\text { Building leg }\end{array}$} & $89(55)$ & $7.62(3)$ & $\begin{array}{l}7,300 \\
(16,000) \\
\end{array}$ & 30 & None \\
\hline & $81(50)$ & 7.62 (3) & $\begin{array}{l}7,300 \\
(16,000) \\
\end{array}$ & 20 & Escorts \\
\hline & $72(45)$ & $7.62(3)$ & $\begin{array}{l}7,300 \\
(16,000) \\
\end{array}$ & 30 & Escorts \\
\hline & $81(50)$ & $7.62(3)$ & $\begin{array}{l}7,300 \\
(16,000) \\
\end{array}$ & 15 & $\begin{array}{l}\text { Road closed, escorts, off-peak hours, } \\
\text { etc. }\end{array}$ \\
\hline & $89(55)$ & 7.62 (3) & $\begin{array}{l}>7,300 \\
(16,000)\end{array}$ & 15 & Escorts \\
\hline
\end{tabular}

* Seals can fail; cask maintains structural integrity.

\section{ALL OPTIONS:}

Puncture: $7.6 \mathrm{~cm}$ (3 in.) of steel or steel equivalent

Crush: Survives 7,300-kg (16,000-1b) crush force highway mode, $31,000-\mathrm{kg}(68,000-1 \mathrm{~b})$ crush rail mode

\section{Administrative}

Controls: All highway postings and applicable state laws and normal Hanford Site administrative controls for the onsite transport of spent fuel by truck

\section{CVD TRANSPORT OPTION 1:}

Impact: $40-\mathrm{km} / \mathrm{h}(25-\mathrm{mph})$ change in velocity on to a typical Hanford Site surface

Fire: Survives a 10 -minute engulfing $800^{\circ} \mathrm{C}\left(1,475^{\circ} \mathrm{F}\right)$ fire with no catastrophic loss of contents or loss of MCO confinement; no net loss of shielding is allowed; external cooling after

Additional 10 minutes is permitted

Administrative

Controls: Escorts or closing the road to other vehicles and an optional $24-\mathrm{km} / \mathrm{h}$ (15-mph) speed limit on the vehicle transporting the cask 
CVD TRANSPORT OPTION 2:

Impact: $40-\mathrm{km} / \mathrm{h}(25-\mathrm{mph})$ change in velocity on to a typical Hanford Site surface

Fire: Survives a 15 -minute engulfing $800^{\circ} \mathrm{C}\left(1,475^{\circ} \mathrm{F}\right)$ fire with no catastrophic loss of contents or loss of MCO confinement; no net loss of shielding is allowed; external cooling after

Additional 15 minutes is permitted

Administrative

Controls: None

CVD TRANSPORT OPTION 3:

Impact: $40-\mathrm{km} / \mathrm{h}(25-\mathrm{mph})$ change in velocity on to a typical Hanford Site surface

Fire: Fails any fire

Additional

Administrative

Controls: Escorts or closing the road to other vehicles

CSB TRANSPORT OPTION 1:

Impact: $89-\mathrm{km} / \mathrm{h}(55-\mathrm{mph})$ change in velocity on to a typical Hanford Site surface

Fire: Survives a 30 -minute engulfing $800^{\circ} \mathrm{C}\left(1,475^{\circ} \mathrm{F}\right)$ fire with no catastrophic loss of contents or loss of MCO confinement; no net loss of shielding is allowed; external cooling after

Additional 30 minutes is permitted

Administrative

Controls: None

CSB TRANSPORT OPTION 2:

Impact: $81-\mathrm{km} / \mathrm{h}(50-\mathrm{mph})$ change in velocity on to a typical Hanford Site surface

Fire: Survives a 20 -minute engulfing $800^{\circ} \mathrm{C}\left(1,475^{\circ} \mathrm{F}\right)$ fire with no catastrophic loss of contents or loss of MCO confinement; no net loss of shielding is allowed; external cooling after

Additional 20 minutes is permitted

Administrative

Controls: Escorts 
CSB TRANSPORT OPTION 3:

Impact: $72-\mathrm{km} / \mathrm{h}(45-\mathrm{mph})$ change in velocity on to a typical Hanford Site surface

Fire: Survives a 30 -minute engulfing $800^{\circ} \mathrm{C}\left(1,475^{\circ} \mathrm{F}\right)$ fire with no catastrophic loss of contents or loss of MCO confinement; no net loss of shielding is allowed; external cooling after

Additional 30 minutes is permitted

Administrative

Controls: Escorts

CSB TRANSPORT OPTION 4:

Impact: $81-\mathrm{km} / \mathrm{h}(50-\mathrm{mph})$ change in velocity on to a typical Hanford Site surface

Fire: Survives a 15 -minute engulfing $800^{\circ} \mathrm{C}\left(1,475^{\circ} \mathrm{F}\right)$ fire with no catastrophic loss of contents or loss of MCO confinement; no net loss of shielding is allowed; external cooling after

Additional 15 minutes is permitted

Administrative

Controls: Roads closed, escorts, shipping during off-peak hours, and prior notification of emergency responders

\section{CSB TRANSPORT OPTION 5:}

Impact: $89-\mathrm{km} / \mathrm{h}(55-\mathrm{mph})$ change in velocity on to a typical Hanford Site surface

Fire: Survives a 15 -minute engulfing $800^{\circ} \mathrm{C}\left(1,475^{\circ} \mathrm{F}\right)$ fire with no catastrophic loss of contents or loss of MCO confinement; no net loss of shielding is allowed; external cooling after

Additional 15 minutes is permitted

Administrative

Controls: Escorts

The annual accident release frequency associated with the developed design criteria and administrative controls, as listed above, fall within the criteria set in Section 3.0. This ensures that onsite transportation safety requirements have been met for use of the MCO cask in the transport of irradiated nuclear fuel from the K Basins to the 200 East Area. 


\subsection{REFERENCES}

Dennis, A. W., et al., 1978, Severities of Transportation Accidents Involving Large Packages, SAND77-0001, Sandia National Laboratories, Albuquerque, New Mexico.

Green, J. R., B. D. Flanagan, and H. Harris, 1996, Hanford Site Truck Accident Rate, 1990-1995, WHC-SD-TP-RPT-021, Rev. 0, Westinghouse Hanford Company, Richland, Washington.

H\&R, 1995, Recommended Onsite Transportation Risk Management Methodology, 522-1, H\&R Technical Associates, Inc., Oak Ridge, Tennessee.

Mercado, J. E., 1994, Report on Equivalent Safety for Transportation and Packaging of Radioactive Materials, WHC-SD-TP-RPT-001, Rev. 0 , Westinghouse Hanford Company, Richland, Washington.

WHC-CM-2-14, Hazardous Material Packaging and Shipping, Westinghouse Hanford Company, Richland, Washington. 